\title{
Free fatty acid receptors (version 2019.4) in the IUPHAR/BPS Guide to Pharmacology Database
} \author{
Leigh Stoddart ${ }^{5}$ \\ 1. Johnson \& Johnson Pharmaceutical Research \& Development, USA \\ 2. GlaxoSmithKline, UK \\ 3. University of Nottingham, UK \\ 4. Tanabe Research Laboratories, USA \\ 5. University of Glasgow, UK \\ 6. University of Edinburgh, UK
}

Celia Briscoe ${ }^{1}$, Andrew Brown², Nick Holliday ${ }^{3}$, Stephen Jenkinson ${ }^{4}$, Graeme Milligan ${ }^{5}$, Amy E. Monaghan $^{6}$ and $^{2}$

\begin{abstract}
Free fatty acid receptors (FFA, nomenclature as agreed by the NC-IUPHAR Subcommittee on free fatty acid receptors $[111,24]$ ) are activated by free fatty acids. Long-chain saturated and unsaturated fatty acids (including C14.0 (myristic acid), C16:0 (palmitic acid), C18:1 (oleic acid), C18:2 (linoleic acid), C18:3, ( $\alpha$ linolenic acid), C20:4 (arachidonic acid), C20:5,n-3 (EPA) and C22:6,n-3 (docosahexaenoic acid)) activate FFA1 [8, 50, 60] and FFA4 receptors [41, 48, 90], while short chain fatty acids (C2 (acetic acid), C3 (propanoic acid), C4 (butyric acid) and C5 (pentanoic acid)) activate FFA2 [9, 62, 86] and FFA3 [9, 62] receptors. The crystal structure for agonist bound FFA1 has been described [108].
\end{abstract}

\section{Contents}

This is a citation summary for Free fatty acid receptors in the Guide to Pharmacology database (GtoPdb). It exists purely as an adjunct to the database to facilitate the recognition of citations to and from the database by citation analyzers. Readers will almost certainly want to visit the relevant sections of the database which are given here under database links.

GtoPdb is an expert-driven guide to pharmacological targets and the substances that act on them. GtoPdb is a reference work which is most usefully represented as an on-line database. As in any publication this work should be appropriately cited, and the papers it cites should also be recognized. This document provides a citation for the relevant parts of the database, and also provides a reference list for the research cited by those parts.

Please note that the database version for the citations given in GtoPdb are to the most recent preceding version in which the family or its subfamilies and targets were substantially changed. The links below are to the current version. If you need to consult the cited version, rather than the most recent version, please contact the GtoPdb curators.

\section{Database links}


Free fatty acid receptors

http://www.guidetopharmacology.org/GRAC/FamilyDisplayForward?familyld=24

Introduction to Free fatty acid receptors

http://www.guidetopharmacology.org/GRAC/FamilylntroductionForward?familyld=24

Receptors

FFA1 receptor

http://www.guidetopharmacology.org/GRAC/ObjectDisplayForward?objectld=225

FFA2 receptor

http://www.guidetopharmacology.org/GRAC/ObjectDisplayForward?objectld=226

FFA3 receptor

http://www.guidetopharmacology.org/GRAC/ObjectDisplayForward?objectld=227

FFA4 receptor

http://www.guidetopharmacology.org/GRAC/ObjectDisplayForward?objectld=127

GPR42

http://www.guidetopharmacology.org/GRAC/ObjectDisplayForward?objectld=228

\section{References}

1. Adachi T, Yanaka H, Kanai H, Nozaki M, Takahara Y, Tsuda M, Jonouchi T, Tsuda K, Hirasawa A and Tsujimoto G. (2008) Administration of perilla oil coated with Calshell increases glucagon-like peptide secretion. Biol. Pharm. Bull. 31: 1021-3 [PMID:18451539]

2. Bellahcene M, O'Dowd JF, Wargent ET, Zaibi MS, Hislop DC, Ngala RA, Smith DM, Cawthorne MA, Stocker CJ and Arch JR. (2013) Male mice that lack the G-protein-coupled receptor GPR41 have low energy expenditure and increased body fat content. Br. J. Nutr. 109: 1755-64 [PMID:23110765]

3. Berggren AM, Nyman EM, Lundquist I and Björck IM. (1996) Influence of orally and rectally administered propionate on cholesterol and glucose metabolism in obese rats. Br. J. Nutr. 76: 287-94 [PMID:8813902]

4. Bjursell M, Admyre T, Göransson M, Marley AE, Smith DM, Oscarsson J and Bohlooly-Y M. (2011) Improved glucose control and reduced body fat mass in free fatty acid receptor 2-deficient mice fed a highfat diet. Am. J. Physiol. Endocrinol. Metab. 300: E211-20 [PMID:20959533]

5. Bolognini D, Moss CE, Nilsson K, Petersson AU, Donnelly I, Sergeev E, König GM, Kostenis E, KurowskaStolarska M and Miller A et al.. (2016) A Novel Allosteric Activator of Free Fatty Acid 2 Receptor Displays Unique Gi-functional Bias. J. Biol. Chem. 291: 18915-31 [PMID:27385588]

6. Bonini JA, Anderson SM and Steiner DF. (1997) Molecular cloning and tissue expression of a novel orphan G protein-coupled receptor from rat lung. Biochem. Biophys. Res. Commun. 234: 190-3 [PMID:9168987]

7. Briscoe CP, Peat AJ, McKeown SC, Corbett DF, Goetz AS, Littleton TR, McCoy DC, Kenakin TP, Andrews $\mathrm{JL}$ and Ammala C et al.. (2006) Pharmacological regulation of insulin secretion in MIN6 cells through the fatty acid receptor GPR40: identification of agonist and antagonist small molecules. Br. J. Pharmacol. 148: 619-28 [PMID:16702987]

8. Briscoe CP, Tadayyon M, Andrews JL, Benson WG, Chambers JK, Eilert MM, Ellis C, Elshourbagy NA, Goetz AS and Minnick DT et al.. (2003) The orphan G protein-coupled receptor GPR40 is activated by medium and long chain fatty acids. J. Biol. Chem. 278: 11303-11 [PMID:12496284]

9. Brown AJ, Goldsworthy SM, Barnes AA, Eilert MM, Tcheang L, Daniels D, Muir Al, Wigglesworth MJ, Kinghorn I and Fraser NJ et al.. (2003) The Orphan G protein-coupled receptors GPR41 and GPR43 are activated by propionate and other short chain carboxylic acids. J. Biol. Chem. 278: 11312-9 [PMID:12496283]

10. Brown AJ, Jupe S and Briscoe CP. (2005) A family of fatty acid binding receptors.DNA Cell Biol. 24: 5461 [PMID:15684720]

11. Burns RN and Moniri NH. (2010) Agonism with the omega-3 fatty acids alpha-linolenic acid and docosahexaenoic acid mediates phosphorylation of both the short and long isoforms of the human GPR120 receptor. Biochem. Biophys. Res. Commun. 396: 1030-5 [PMID:20471368] 
12. Cartoni C, Yasumatsu K, Ohkuri T, Shigemura N, Yoshida R, Godinot N, le Coutre J, Ninomiya Y and Damak S. (2010) Taste preference for fatty acids is mediated by GPR40 and GPR120. J. Neurosci. 30: 8376-82 [PMID:20573884]

13. Cherbut C, Ferrier L, Rozé C, Anini Y, Blottière H, Lecannu G and Galmiche JP. (1998) Short-chain fatty acids modify colonic motility through nerves and polypeptide YY release in the rat. Am. J. Physiol. 275: G1415-22 [PMID:9843779]

14. Christiansen E, Due-Hansen ME, Urban C, Grundmann M, Schröder R, Hudson BD, Milligan G, Cawthorne MA, Kostenis E and Kassack MU et al.. (2012) Free fatty acid receptor 1 (FFA1/GPR40) agonists: mesylpropoxy appendage lowers lipophilicity and improves ADME properties. J. Med. Chem. 55: 6624-8 [PMID:22724451]

15. Christiansen E, Hansen SV, Urban C, Hudson BD, Wargent ET, Grundmann M, Jenkins L, Zaibi M, Stocker CJ and Ullich S et al.. (2013) Discovery of TUG-770: A Highly Potent Free Fatty Acid Receptor 1 (FFA1/GPR40) Agonist for Treatment of Type 2 Diabetes. ACS Med Chem Lett 4: 441-445 [PMID:23687558]

16. Christiansen E, Hudson BD, Hansen AH, Milligan G and Ulven T. (2016) Development and Characterization of a Potent Free Fatty Acid Receptor 1 (FFA1) Fluorescent Tracer. J. Med. Chem. 59: 4849-58 [PMID:27074625]

17. Christiansen E, Urban C, Merten N, Liebscher K, Karlsen KK, Hamacher A, Spinrath A, Bond AD, Drewke $C$ and Ullrich $S$ et al.. (2008) Discovery of potent and selective agonists for the free fatty acid receptor 1 (FFA(1)/GPR40), a potential target for the treatment of type II diabetes. J. Med. Chem. 51: 7061-4 [PMID:18947221]

18. Christiansen E, Watterson KR, Stocker CJ, Sokol E, Jenkins L, Simon K, Grundmann M, Petersen RK, Wargent ET and Hudson BD et al.. (2015) Activity of dietary fatty acids on FFA1 and FFA4 and characterisation of pinolenic acid as a dual FFA1/FFA4 agonist with potential effect against metabolic diseases. Br. J. Nutr. 113: 1677-88 [PMID:25916176]

19. Cintra DE, Ropelle ER, Moraes JC, Pauli JR, Morari J, Souza CT, Grimaldi R, Stahl M, Carvalheira JB and Saad MJ et al.. (2012) Unsaturated fatty acids revert diet-induced hypothalamic inflammation in obesity. PLoS ONE 7: e30571 [PMID:22279596]

20. Cornall LM, Mathai ML, Hryciw DH and McAinch AJ. (2011) Diet-induced obesity up-regulates the abundance of GPR43 and GPR120 in a tissue specific manner. Cell. Physiol. Biochem. 28: 949-58 [PMID:22178946]

21. Cornish J, MacGibbon A, Lin JM, Watson M, Callon KE, Tong PC, Dunford JE, van der Does Y, Williams GA, Grey AB, Naot D and Reid IR. (2008) Modulation of osteoclastogenesis by fatty acids. Endocrinology 149: 5688-95 [PMID:18617622]

22. Covington DK, Briscoe CA, Brown AJ and Jayawickreme CK. (2006) The G-protein-coupled receptor 40 family (GPR40-GPR43) and its role in nutrient sensing. Biochem. Soc. Trans. 34: 770-3 [PMID:17052194]

23. Dass NB, John AK, Bassil AK, Crumbley CW, Shehee WR, Maurio FP, Moore GB, Taylor CM and Sanger GJ. (2007) The relationship between the effects of short-chain fatty acids on intestinal motility in vitro and GPR43 receptor activation. Neurogastroenterol. Motil. 19: 66-74 [PMID:17187590]

24. Davenport AP, Alexander SP, Sharman JL, Pawson AJ, Benson HE, Monaghan AE, Liew WC, Mpamhanga CP, Bonner TI and Neubig RR et al.. (2013) International Union of Basic and Clinical Pharmacology. LXXXVIII. G protein-coupled receptor list: recommendations for new pairings with cognate ligands. Pharmacol. Rev. 65: 967-86 [PMID:23686350]

25. Duca FA, Swartz TD, Sakar Y and Covasa M. (2013) Decreased intestinal nutrient response in dietinduced obese rats: role of gut peptides and nutrient receptors. Int J Obes (Lond) 37: 375-81 [PMID:22546775]

26. Engelstoft MS, Egerod KL, Holst B and Schwartz TW. (2008) A gut feeling for obesity: 7TM sensors on enteroendocrine cells. Cell Metab. 8: 447-9 [PMID:19041758]

27. Feng DD, Luo Z, Roh SG, Hernandez M, Tawadros N, Keating DJ and Chen C. (2006) Reduction in voltage-gated $\mathrm{K}+$ currents in primary cultured rat pancreatic beta-cells by linoleic acids. Endocrinology 147: 
674-682 [PMID:16254037]

28. Flodgren E, Olde B, Meidute-Abaraviciene S, Winzell MS, Ahrén B and Salehi A. (2007) GPR40 is expressed in glucagon producing cells and affects glucagon secretion. Biochem. Biophys. Res. Commun. 354: 240-5 [PMID:17214971]

29. Fredriksson R, Höglund PJ, Gloriam DE, Lagerström MC and Schiöth HB. (2003) Seven evolutionarily conserved human rhodopsin $G$ protein-coupled receptors lacking close relatives. FEBS Lett. 554: 381-8 [PMID:14623098]

30. Fukumoto S, Tatewaki M, Yamada T, Fujimiya M, Mantyh C, Voss M, Eubanks S, Harris M, Pappas TN and Takahashi T. (2003) Short-chain fatty acids stimulate colonic transit via intraluminal 5-HT release in rats. Am. J. Physiol. Regul. Integr. Comp. Physiol.284: R1269-76 [PMID:12676748]

31. Fukunaga $S$, Setoguchi S, Hirasawa A and Tsujimoto G. (2006) Monitoring ligand-mediated internalization of $G$ protein-coupled receptor as a novel pharmacological approach. Life Sci. 80: 17-23 [PMID:16978657]

32. Gagnon L, Leduc M, Thibodeau JF, Zhang MZ, Grouix B, Sarra-Bournet F, Gagnon W, Hince K, Tremblay $M$ and Geerts L et al.. (2018) A Newly Discovered Antifibrotic Pathway Regulated by Two Fatty Acid Receptors: GPR40 and GPR84. Am. J. Pathol. 188: 1132-1148 [PMID:29454750]

33. Garrel G, Simon V, Denoyelle C, Cruciani-Guglielmacci C, Migrenne S, Counis R, Magnan C and CohenTannoudji J. (2011) Unsaturated fatty acids stimulate LH secretion via novel PKCepsilon and -theta in gonadotrope cells and inhibit GnRH-induced LH release. Endocrinology 152: 3905-16 [PMID:21862612]

34. Garrido DM, Corbett DF, Dwornik KA, Goetz AS, Littleton TR, McKeown SC, Mills WY, Smalley Jr TL, Briscoe CP and Peat AJ. (2006) Synthesis and activity of small molecule GPR40 agonists. Bioorg. Med. Chem. Lett. 16: 1840-5 [PMID:16439116]

35. Gotoh C, Hong YH, Iga T, Hishikawa D, Suzuki Y, Song SH, Choi KC, Adachi T, Hirasawa A, Tsujimoto G, Sasaki S and Roh SG. (2007) The regulation of adipogenesis through GPR120. Biochem. Biophys. Res. Commun. 354: 591-7 [PMID:17250804]

36. Hamid YH, Vissing H, Holst B, Urhammer SA, Pyke C, Hansen SK, Glümer C, Borch-Johnsen K, Jørgensen T and Schwartz TW et al.. (2005) Studies of relationships between variation of the human $G$ protein-coupled receptor 40 Gene and Type 2 diabetes and insulin release. Diabet. Med. 22: 74-80 [PMID:15606695]

37. Hara T, Hirasawa A, Ichimura A, Kimura I and Tsujimoto G. (2011) Free fatty acid receptors FFAR1 and GPR120 as novel therapeutic targets for metabolic disorders. J Pharm Sci 100: 3594-601 [PMID:21618241]

38. Hara T, Hirasawa A, Sun Q, Sadakane K, Itsubo C, Iga T, Adachi T, Koshimizu TA, Hashimoto T and Asakawa $Y$ et al.. (2009) Novel selective ligands for free fatty acid receptors GPR120 and GPR40.Naunyn Schmiedebergs Arch. Pharmacol. 380: 247-55 [PMID:19471906]

39. Hardy S, St-Onge GG, Joly E, Langelier Y and Prentki M. (2005) Oleate promotes the proliferation of breast cancer cells via the G protein-coupled receptor GPR40. J. Biol. Chem. 280: 13285-91 [PMID:15695516]

40. Hirasawa A, Hara T, Katsuma S, Adachi T and Tsujimoto G. (2008) Free fatty acid receptors and drug discovery. Biol. Pharm. Bull. 31: 1847-51 [PMID:18827341]

41. Hirasawa A, Tsumaya K, Awaji T, Katsuma S, Adachi T, Yamada M, Sugimoto Y, Miyazaki S and Tsujimoto G. (2005) Free fatty acids regulate gut incretin glucagon-like peptide-1 secretion through GPR120. Nat Med 11: 90-94 [PMID:15619630]

42. Holliday ND, Watson SJ and Brown AJ. (2011) Drug discovery opportunities and challenges at g protein coupled receptors for long chain free Fatty acids. Front Endocrinol (Lausanne) 2: 112 [PMID:22649399]

43. Hong YH, Nishimura Y, Hishikawa D, Tsuzuki H, Miyahara H, Gotoh C, Choi KC, Feng DD, Chen $C$ and Lee HG et al.. (2005) Acetate and propionate short chain fatty acids stimulate adipogenesis via GPCR43. Endocrinology 146: 5092-9 [PMID:16123168]

44. Hudson BD, Christiansen E, Murdoch H, Jenkins L, Hansen AH, Madsen O, Ulven T and Milligan G. (2014) Complex pharmacology of novel allosteric free fatty acid 3 receptor ligands. Mol. Pharmacol. 86: 200-10 [PMID:24870406] 
45. Hudson BD, Christiansen E, Tikhonova IG, Grundmann M, Kostenis E, Adams DR, Ulven T and Milligan G. (2012) Chemically engineering ligand selectivity at the free fatty acid receptor 2 based on pharmacological variation between species orthologs. FASEB J. 26: 4951-65 [PMID:22919070]

46. Hudson BD, Due-Hansen ME, Christiansen E, Hansen AM, Mackenzie AE, Murdoch H, Pandey SK, Ward RJ, Marquez R and Tikhonova IG et al.. (2013) Defining the molecular basis for the first potent and selective orthosteric agonists of the FFA2 free fatty acid receptor. J. Biol. Chem. 288: 17296-312 [PMID:23589301]

47. Hudson BD, Tikhonova IG, Pandey SK, Ulven T and Milligan G. (2012) Extracellular ionic locks determine variation in constitutive activity and ligand potency between species orthologs of the free fatty acid receptors FFA2 and FFA3. J. Biol. Chem. 287: 41195-209 [PMID:23066016]

48. Ichimura A, Hirasawa A, Poulain-Godefroy O, Bonnefond A, Hara T, Yengo L, Kimura I, Leloire A, Liu N and lida K et al.. (2012) Dysfunction of lipid sensor GPR120 leads to obesity in both mouse and human. Nature 483: 350-4 [PMID:22343897]

49. Ito J, Ito M, Nambu H, Fujikawa T, Tanaka K, Iwaasa H and Tokita S. (2009) Anatomical and histological profiling of orphan G-protein-coupled receptor expression in gastrointestinal tract of C57BL/6J mice. Cell Tissue Res. 338: 257-69 [PMID:19763624]

50. Itoh Y, Kawamata Y, Harada M, Kobayashi M, Fujii R, Fukusumi S, Ogi K, Hosoya M, Tanaka Y and Uejima $\mathrm{H}$ et al.. (2003) Free fatty acids regulate insulin secretion from pancreatic beta cells through GPR40. Nature 422: 173-6 [PMID:12629551]

51. Kaku K, Enya K, Nakaya R, Ohira T and Matsuno R. (2015) Efficacy and safety of fasiglifam (TAK-875), a $G$ protein-coupled receptor 40 agonist, in Japanese patients with type 2 diabetes inadequately controlled by diet and exercise: a randomized, double-blind, placebo-controlled, phase III trial. Diabetes Obes Metab 17: 675-81 [PMID:25787200]

52. Karaki S, Mitsui R, Hayashi H, Kato I, Sugiya H, Iwanaga T, Furness JB and Kuwahara A. (2006) Shortchain fatty acid receptor, GPR43, is expressed by enteroendocrine cells and mucosal mast cells in rat intestine. Cell Tissue Res. 324: 353-60 [PMID:16453106]

53. Karaki S, Tazoe H, Hayashi H, Kashiwabara H, Tooyama K, Suzuki Y and Kuwahara A. (2008) Expression of the short-chain fatty acid receptor, GPR43, in the human colon. J. Mol. Histol. 39: 135-42 [PMID:17899402]

54. Katayama S, Tomaru Y, Kasukawa T, Waki K, Nakanishi M, Nakamura M, Nishida H, Yap CC, Suzuki M and Kawai J et al.. (2005) Antisense transcription in the mammalian transcriptome.Science 309: 1564-6 [PMID:16141073]

55. Katsuma S, Hatae N, Yano T, Ruike Y, Kimura M, Hirasawa A and Tsujimoto G. (2005) Free fatty acids inhibit serum deprivation-induced apoptosis through GPR120 in a murine enteroendocrine cell line STC-1. J. Biol. Chem. 280: 19507-15 [PMID:15774482]

56. Kazemian P, Kazemi-Bajestani SM, Alherbish A, Steed J and Oudit GY. (2012) The use of $\omega-3$ polyunsaturated fatty acids in heart failure: a preferential role in patients with diabetes. Cardiovasc Drugs Ther 26: 311-20 [PMID:22644698]

57. Kebede MA, Alquier T, Latour MG and Poitout V. (2009) Lipid receptors and islet function: therapeutic implications? Diabetes Obes Metab 11 Suppl 4: 10-20 [PMID:19817784]

58. Kimura I, Inoue D, Maeda T, Hara T, Ichimura A, Miyauchi S, Kobayashi M, Hirasawa A and Tsujimoto G. (2011) Short-chain fatty acids and ketones directly regulate sympathetic nervous system via $G$ proteincoupled receptor 41 (GPR41). Proc. Natl. Acad. Sci. U.S.A. 108: 8030-5 [PMID:21518883]

59. Kimura M, Mizukami Y, Miura T, Fujimoto K, Kobayashi S and Matsuzaki M. (2001) Orphan G proteincoupled receptor, GPR41, induces apoptosis via a p53/Bax pathway during ischemic hypoxia and reoxygenation. J. Biol. Chem. 276: 26453-60 [PMID:11335718]

60. Kotarsky K, Nilsson NE, Flodgren E, Owman C and Olde B. (2003) A human cell surface receptor activated by free fatty acids and thiazolidinedione drugs. Biochem. Biophys. Res. Commun. 301: 406-10 [PMID:12565875]

61. Latour MG, Alquier T, Oseid E, Tremblay C, Jetton TL, Luo J, Lin DC and Poitout V. (2007) GPR40 is 
necessary but not sufficient for fatty acid stimulation of insulin secretion in vivo. Diabetes 56: 1087-94 [PMID:17395749]

62. Le Poul E, Loison C, Struyf S, Springael JY, Lannoy V, Decobecq ME, Brezillon S, Dupriez V, Vassart G and Van Damme J et al.. (2003) Functional characterization of human receptors for short chain fatty acids and their role in polymorphonuclear cell activation. J. Biol. Chem. 278: 25481-9 [PMID:12711604]

63. Lee T, Schwandner R, Swaminath G, Weiszmann J, Cardozo M, Greenberg J, Jaeckel P, Ge H, Wang Y and Jiao $X$ et al.. (2008) Identification and functional characterization of allosteric agonists for the $G$ protein-coupled receptor FFA2. Mol. Pharmacol. 74: 1599-609 [PMID:18818303]

64. Leonard JN, Chu ZL, Bruce MA and Boatman PD. (2006) Pat 2006;PCT/US/2005/039551 (WO2006/052566 A2). -

65. Leonard JN and Hakak Y. (2006) Pat PCT/US2005/033795(WO 2006/036688 A2). -

66. Liaw CW and Connolly DT. (2009) Sequence polymorphisms provide a common consensus sequence for GPR41 and GPR42. DNA Cell Biol. 28: 555-60 [PMID:19630535]

67. Lin DC, Guo Q, Luo J, Zhang J, Nguyen K, Chen M, Tran T, Dransfield PJ, Brown SP and Houze \&t al.. (2012) Identification and pharmacological characterization of multiple allosteric binding sites on the free fatty acid 1 receptor. Mol. Pharmacol. 82: 843-59 [PMID:22859723]

68. Liou AP, Lu X, Sei Y, Zhao X, Pechhold S, Carrero RJ, Raybould HE and Wank S. (2011) The G-proteincoupled receptor GPR40 directly mediates long-chain fatty acid-induced secretion of cholecystokinin. Gastroenterology 140: 903-12 [PMID:20955703]

69. Lu X, Zhao X, Feng J, Liou AP, Anthony S, Pechhold S, Sun Y, Lu H and Wank S. (2012) Postprandial inhibition of gastric ghrelin secretion by long-chain fatty acid through GPR120 in isolated gastric ghrelin cells and mice. Am. J. Physiol. Gastrointest. Liver Physiol. 303: G367-76 [PMID:22678998]

70. Ma D, Tao B, Warashina S, Kotani S, Lu L, Kaplamadzhiev DB, Mori Y, Tonchev AB and Yamashima T. (2007) Expression of free fatty acid receptor GPR40 in the central nervous system of adult monkeys. Neurosci. Res. 58: 394-401 [PMID:17583366]

71. Ma L, Wang T, Shi M, Fu P, Pei H and Ye H. (2016) Synthesis, Activity, and Docking Study of Novel Phenylthiazole-Carboxamido Acid Derivatives as FFA2 Agonists. Chem Biol Drug Des 88: 26-37 [PMID:26808470]

72. Martin C, Passilly-Degrace P, Gaillard D, Merlin JF, Chevrot M and Besnard P. (2011) The lipid-sensor candidates CD36 and GPR120 are differentially regulated by dietary lipids in mouse taste buds: impact on spontaneous fat preference. PLOS ONE 6: e24014 [PMID:21901153]

73. Maslowski KM, Vieira AT, Ng A, Kranich J, Sierro F, Yu D, Schilter HC, Rolph MS, Mackay F and Artis Det al.. (2009) Regulation of inflammatory responses by gut microbiota and chemoattractant receptor GPR43. Nature 461: 1282-6 [PMID:19865172]

74. Matsumura S, Eguchi A, Mizushige T, Kitabayashi N, Tsuzuki S, Inoue K and Fushiki T. (2009) Colocalization of GPR120 with phospholipase-Cbeta2 and alpha-gustducin in the taste bud cells in mice. Neurosci. Lett. 450: 186-90 [PMID:19071193]

75. Matsumura S, Mizushige T, Yoneda T, Iwanaga T, Tsuzuki S, Inoue K and Fushiki T. (2007) GPR expression in the rat taste bud relating to fatty acid sensing. Biomed. Res. 28: 49-55 [PMID:17379957]

76. McKeown SC, Corbett DF, Goetz AS, Littleton TR, Bigham E, Briscoe CP, Peat AJ, Watson SP and Hickey DM. (2007) Solid phase synthesis and SAR of small molecule agonists for the GPR40 receptor. Bioorg. Med. Chem. Lett. 17: 1584-9 [PMID:17240142]

77. McLarnon A. (2012) Obesity: GPR120 dysfunction can cause obesity in mice and humans.Nat Rev Gastroenterol Hepatol 9: 187 [PMID:22410428]

78. Milligan G, Stoddart LA and Brown AJ. (2006) G protein-coupled receptors for free fatty acids.Cell. Signal. 18: 1360-5 [PMID:16716567]

79. Miyauchi S, Hirasawa A, Iga T, Liu N, Itsubo C, Sadakane K, Hara T and Tsujimoto G. (2009) Distribution and regulation of protein expression of the free fatty acid receptor GPR120. Naunyn Schmiedebergs Arch. Pharmacol. 379: 427-34 [PMID:19145429]

80. Moore K, Zhang Q, Murgolo N, Hosted T and Duffy R. (2009) Cloning, expression, and pharmacological 
characterization of the GPR120 free fatty acid receptor from cynomolgus monkey: comparison with human GPR120 splice variants. Comp. Biochem. Physiol. B, Biochem. Mol. Biol. 154: 419-26 [PMID:19723586]

81. Morgan NG and Dhayal S. (2009) G-protein coupled receptors mediating long chain fatty acid signalling in the pancreatic beta-cell. Biochem. Pharmacol. 78: 1419-27 [PMID:19660440]

82. Nakajima T, likura M, Okayama Y, Matsumoto K, Uchiyama C, Shirakawa T, Yang X, Adra CN, Hirai K and Saito H. (2004) Identification of granulocyte subtype-selective receptors and ion channels by using a high-density oligonucleotide probe array. J. Allergy Clin. Immunol. 113: 528-35 [PMID:15007357]

83. Namour F, Galien R, Van Kaem T, Van der Aa A, Vanhoutte F, Beetens J and Van't Klooster G. (2016) Safety, pharmacokinetics and pharmacodynamics of GLPG0974, a potent and selective FFA2 antagonist, in healthy male subjects. Br J Clin Pharmaco/ 82: 139-48 [PMID:26852904]

84. Navarro-Tito N, Robledo T and Salazar EP. (2008) Arachidonic acid promotes FAK activation and migration in MDA-MB-231 breast cancer cells. Exp. Cell Res. 314: 3340-55 [PMID:18804105]

85. Negoro N, Sasaki S, Mikami S, Ito M, Suzuki M, Tsujihata Y, Ito R, Harada A, Takeuchi K and Suzuki Net al.. (2010) Discovery of TAK-875: A Potent, Selective, and Orally Bioavailable GPR40 Agonist ACS Med Chem Lett 1: 290-4 [PMID:24900210]

86. Nilsson NE, Kotarsky K, Owman C and Olde B. (2003) Identification of a free fatty acid receptor, FFA2R, expressed on leukocytes and activated by short-chain fatty acids. Biochem. Biophys. Res. Commun. 303: 1047-52 [PMID:12684041]

87. Ogawa T, Hirose H, Miyashita K, Saito I and Saruta T. (2005) GPR40 gene Arg211His polymorphism may contribute to the variation of insulin secretory capacity in Japanese men. Metab. Clin. Exp. 54: 296-9 [PMID:15736105]

88. Oh da Y, Walenta E, Akiyama TE, Lagakos WS, Lackey D, Pessentheiner AR, Sasik R, Hah N, Chi TJ and Cox JM et al.. (2014) A Gpr120-selective agonist improves insulin resistance and chronic inflammation in obese mice. Nat. Med. 20: 942-7 [PMID:24997608]

89. Oh DY and Olefsky JM. (2012) Omega 3 fatty acids and GPR120.Cell Metab. 15: 564-5 [PMID:22560206]

90. Oh DY, Talukdar S, Bae EJ, Imamura T, Morinaga H, Fan W, Li P, Lu WJ, Watkins SM and Olefsky JM. (2010) GPR120 is an omega-3 fatty acid receptor mediating potent anti-inflammatory and insulinsensitizing effects. Cell 142: 687-98 [PMID:20813258]

91. Parker HE, Habib AM, Rogers GJ, Gribble FM and Reimann F. (2009) Nutrient-dependent secretion of glucose-dependent insulinotropic polypeptide from primary murine K cells. Diabetologia 52: 289-98 [PMID:19082577]

92. Pizzonero M, Dupont S, Babel M, Beaumont S, Bienvenu N, Blanqué R, Cherel L, Christophe T, Crescenzi $B$ and De Lemos E et al.. (2014) Discovery and optimization of an azetidine chemical series as a free fatty acid receptor 2 (FFA2) antagonist: from hit to clinic. J. Med. Chem. 57: 10044-57 [PMID:25380412]

93. Rasoamanana R, Darcel N, Fromentin G and Tomé D. (2012) Nutrient sensing and signalling by the gut. Proc Nutr Soc 71: 446-55 [PMID:22453062]

94. Reber SO, Birkeneder L, Veenema AH, Obermeier F, Falk W, Straub RH and Neumann ID. (2007) Adrenal insufficiency and colonic inflammation after a novel chronic psycho-social stress paradigm in mice: implications and mechanisms. Endocrinology 148: 670-82 [PMID:17110427]

95. Saltiel AR. (2010) Fishing out a sensor for anti-inflammatory oils. Cell 142: 672-4 [PMID:20813253]

96. Samuel BS, Shaito A, Motoike T, Rey FE, Backhed F, Manchester JK, Hammer RE, Williams SC, Crowley $\mathrm{J}$ and Yanagisawa $\mathrm{M}$ et al.. (2008) Effects of the gut microbiota on host adiposity are modulated by the short-chain fatty-acid binding G protein-coupled receptor, Gpr41. Proc. Natl. Acad. Sci. U.S.A. 105: 1676772 [PMID:18931303]

97. Sawzdargo M, George SR, Nguyen T, Xu S, Kolakowski LF and O'Dowd BF. (1997) A cluster of four novel human $G$ protein-coupled receptor genes occurring in close proximity to CD22 gene on chromosome 19q13.1. Biochem. Biophys. Res. Commun. 239: 543-7 [PMID:9344866]

98. Schmidt J, Smith NJ, Christiansen E, Tikhonova IG, Grundmann M, Hudson BD, Ward RJ, Drewke C, Milligan $G$ and Kostenis $E$ et al.. (2011) Selective orthosteric free fatty acid receptor 2 (FFA2) agonists: identification of the structural and chemical requirements for selective activation of FFA2 versus FFA3. J. 
Biol. Chem. 286: 10628-40 [PMID:21220428]

99. Schröder R, Janssen N, Schmidt J, Kebig A, Merten N, Hennen S, Müller A, Blättermann S, Mohr-Andrä M and Zahn $S$ et al.. (2010) Deconvolution of complex G protein-coupled receptor signaling in live cells using dynamic mass redistribution measurements. Nat. Biotechnol. 28: 943-9 [PMID:20711173]

100. Seljeset $S$ and Siehler S. (2012) Receptor-specific regulation of ERK $1 / 2$ activation by members of the "free fatty acid receptor" family. J. Recept. Signal Transduct. Res. 32: 196-201 [PMID:22712802]

101. Senga T, Iwamoto S, Yoshida T, Yokota T, Adachi K, Azuma E, Hamaguchi M and Iwamoto T. (2003) LSSIG is a novel murine leukocyte-specific GPCR that is induced by the activation of STAT3. Blood 101: 1185-7 [PMID:12393494]

102. Shimpukade B, Hudson BD, Hovgaard CK, Milligan G and Ulven T. (2012) Discovery of a potent and selective GPR120 agonist. J. Med. Chem. 55: 4511-5 [PMID:22519963]

103. Sina C, Gavrilova O, Förster M, Till A, Derer S, Hildebrand F, Raabe B, Chalaris A, Scheller J and Rehmann A et al.. (2009) G protein-coupled receptor 43 is essential for neutrophil recruitment during intestinal inflammation. J. Immunol. 183: 7514-22 [PMID:19917676]

104. Smith NJ, Ward RJ, Stoddart LA, Hudson BD, Kostenis E, Ulven T, Morris JC, Tränkle C, Tikhonova IG and Adams DR et al.. (2011) Extracellular loop 2 of the free fatty acid receptor 2 mediates allosterism of a phenylacetamide ago-allosteric modulator. Mol. Pharmacol. 80: 163-73 [PMID:21498659]

105. Song F, Lu S, Gunnet J, Xu JZ, Wines P, Proost J, Liang Y, Baumann C, Lenhard J and Murray Wlet al.. (2007) Synthesis and biological evaluation of 3-aryl-3-(4-phenoxy)-propionic acid as a novel series of $G$ protein-coupled receptor 40 agonists. J. Med. Chem. 50: 2807-17 [PMID:17500511]

106. Soto-Guzman A, Robledo T, Lopez-Perez M and Salazar EP. (2008) Oleic acid induces ERK1/2 activation and AP-1 DNA binding activity through a mechanism involving Src kinase and EGFR transactivation in breast cancer cells. Mol. Cell. Endocrinol. 294: 81-91 [PMID:18775472]

107. Spector AA and Hoak JC. (1975) Letter: Fatty acids, platelets, and microcirculatory obstruction.Science 190: 490-2 [PMID:1166323]

108. Srivastava A, Yano J, Hirozane Y, Kefala G, Gruswitz F, Snell G, Lane W, Ivetac A, Aertgeerts K and Nguyen J et al.. (2014) High-resolution structure of the human GPR40 receptor bound to allosteric agonist TAK-875. Nature 513: 124-7 [PMID:25043059]

109. Steneberg P, Rubins N, Bartoov-Shifman R, Walker MD and Edlund H. (2005) The FFA receptor GPR40 links hyperinsulinemia, hepatic steatosis, and impaired glucose homeostasis in mouse. Cell Metab. 1: 24558 [PMID:16054069]

110. Stoddart LA, Brown AJ and Milligan G. (2007) Uncovering the pharmacology of the G protein-coupled receptor GPR40: high apparent constitutive activity in guanosine 5'-O-(3-[35S]thio)triphosphate binding studies reflects binding of an endogenous agonist. Mol. Pharmacol. 71: 994-1005 [PMID:17200419]

111. Stoddart LA, Smith NJ and Milligan G. (2008) International Union of Pharmacology. LXXI. Free fatty acid receptors FFA1, -2, and -3: pharmacology and pathophysiological functions. Pharmacol. Rev. 60: 405-17 [PMID:19047536]

112. Sum CS, Tikhonova IG, Neumann S, Engel S, Raaka BM, Costanzi S and Gershengorn MC. (2007) Identification of residues important for agonist recognition and activation in GPR40. J. Biol. Chem. 282: 29248-55 [PMID:17699519]

113. Sun Q, Hirasawa A, Hara T, Kimura I, Adachi T, Awaji T, Ishiguro M, Suzuki T, Miyata N and Tsujimoto G. (2010) Structure-Activity Relationships of GPR120 Agonists Based on a Docking Simulation. Mol. Pharmacol. 78: 804-10 [PMID:20685848]

114. Suzuki T, Igari $S$, Hirasawa $A$, Hata M, Ishiguro M, Fujieda $H$, Itoh $Y$, Hirano $T$, Nakagawa $H$ and Ogura $M$ et al.. (2008) Identification of $\mathrm{G}$ protein-coupled receptor 120-selective agonists derived from PPARgamma agonists. J. Med. Chem. 51: 7640-4 [PMID:19007110]

115. Sykaras AG, Demenis C, Case RM, McLaughlin JT and Smith CP. (2012) Duodenal enteroendocrine Icells contain $\mathrm{mRNA}$ transcripts encoding key endocannabinoid and fatty acid receptors. PLOS ONE 7: e42373 [PMID:22876318]

116. Takeuchi M, Hirasawa A, Hara T, Kimura I, Hirano T, Suzuki T, Miyata N, Awaji T, Ishiguro M and 
Tsujimoto G. (2013) FFA1-selective agonistic activity based on docking simulation using FFA1 and GPR120 homology models. Br. J. Pharmacol. 168: 1570-83 [PMID:22639973]

117. Tan CP, Feng Y, Zhou YP, Eiermann GJ, Petrov A, Zhou C, Lin S, Salituro G, Meinke P and Mosley Pet al.. (2008) Selective small-molecule agonists of $G$ protein-coupled receptor 40 promote glucose-dependent insulin secretion and reduce blood glucose in mice. Diabetes 57: 2211-9 [PMID:18477808]

118. Tanaka T, Katsuma S, Adachi T, Koshimizu TA, Hirasawa A and Tsujimoto G. (2008) Free fatty acids induce cholecystokinin secretion through GPR120. Naunyn Schmiedebergs Arch. Pharmacol. 377: 523-7 [PMID:17972064]

119. Tanaka T, Yano T, Adachi T, Koshimizu TA, Hirasawa A and Tsujimoto G. (2008) Cloning and characterization of the rat free fatty acid receptor GPR120: in vivo effect of the natural ligand on GLP-1 secretion and proliferation of pancreatic beta cells. Naunyn Schmiedebergs Arch. Pharmacol. 377: 515-22 [PMID:18320172]

120. Tang $C$ and Offermanns S. (2017) FFA2 and FFA3 in Metabolic Regulation.Handb Exp Pharmaco/236: 205-220 [PMID:27757760]

121. Tang Y, Chen Y, Jiang H, Robbins GT and Nie D. (2011) G-protein-coupled receptor for short-chain fatty acids suppresses colon cancer. Int. J. Cancer 128: 847-56 [PMID:20979106]

122. Tazoe H, Otomo Y, Karaki S, Kato I, Fukami Y, Terasaki M and Kuwahara A. (2009) Expression of shortchain fatty acid receptor GPR41 in the human colon. Biomed. Res. 30: 149-56 [PMID:19574715]

123. Tikhonova IG, Sum CS, Neumann S, Thomas CJ, Raaka BM, Costanzi S and Gershengorn MC. (2007) Bidirectional, iterative approach to the structural delineation of the functional "chemoprint" in GPR40 for agonist recognition. J. Med. Chem. 50: 2981-9 [PMID:17552505]

124. Tolhurst G, Heffron H, Lam YS, Parker HE, Habib AM, Diakogiannaki E, Cameron J, Grosse J, Reimann F and Gribble FM. (2012) Short-chain fatty acids stimulate glucagon-like peptide-1 secretion via the Gprotein-coupled receptor FFAR2. Diabetes 61: 364-71 [PMID:22190648]

125. Tomita T, Masuzaki H, Iwakura H, Fujikura J, Noguchi M, Tanaka T, Ebihara K, Kawamura J, Komoto I and Kawaguchi $Y$ et al.. (2006) Expression of the gene for a membrane-bound fatty acid receptor in the pancreas and islet cell tumours in humans: evidence for GPR40 expression in pancreatic beta cells and implications for insulin secretion. Diabetologia 49: 962-8 [PMID:16525841]

126. Tsujihata $Y$, Ito R, Suzuki M, Harada A, Negoro N, Yasuma T, Momose $Y$ and Takeuchi K. (2011) TAK875 , an orally available $G$ protein-coupled receptor $40 /$ free fatty acid receptor 1 agonist, enhances glucose-dependent insulin secretion and improves both postprandial and fasting hyperglycemia in type 2 diabetic rats. J. Pharmacol. Exp. Ther. 339: 228-37 [PMID:21752941]

127. Ulven T. (2012) Short-chain free fatty acid receptors FFA2/GPR43 and FFA3/GPR41 as new potential therapeutic targets. Front Endocrinol (Lausanne) 3: 111 [PMID:23060857]

128. Vassilatis DK, Hohmann JG, Zeng H, Li F, Ranchalis JE, Mortrud MT, Brown A, Rodriguez SS, Weller JR and Wright AC et al.. (2003) The G protein-coupled receptor repertoires of human and mouse.Proc. Natl. Acad. Sci. U.S.A. 100: 4903-8 [PMID:12679517]

129. Vinolo MA, Ferguson GJ, Kulkarni S, Damoulakis G, Anderson K, Bohlooly-Y M, Stephens L, Hawkins PT and Curi R. (2011) SCFAs induce mouse neutrophil chemotaxis through the GPR43 receptor. PLoS ONE 6: e21205 [PMID:21698257]

130. Wang A, Akers RM and Jiang H. (2012) Short communication: Presence of G protein-coupled receptor 43 in rumen epithelium but not in the islets of Langerhans in cattle. J. Dairy Sci. 95: 1371-5 [PMID:22365220]

131. Wang J, Wu X, Simonavicius N, Tian H and Ling L. (2006) Medium-chain fatty acids as ligands for orphan G protein-coupled receptor GPR84. J. Biol. Chem. 281: 34457-64 [PMID:16966319]

132. Wang Y, Jiao X, Kayser F, Liu J, Wang Z, Wanska M, Greenberg J, Weiszmann J, Ge H and Tian Het al.. (2010) The first synthetic agonists of FFA2: Discovery and SAR of phenylacetamides as allosteric modulators. Bioorg. Med. Chem. Lett. 20: 493-8 [PMID:20005104]

133. Watson SJ, Brown AJ and Holliday ND. (2012) Differential signaling by splice variants of the human free fatty acid receptor GPR120. Mol. Pharmacol. 81: 631-42 [PMID:22282525]

134. Wellendorph P, Johansen LD and Bräuner-Osborne H. (2009) Molecular pharmacology of promiscuous 
seven transmembrane receptors sensing organic nutrients. Mol. Pharmacol. 76: 453-65 [PMID:19487246]

135. Widmayer P, Küper M, Kramer M, Königsrainer A and Breer H. (2012) Altered expression of gustatorysignaling elements in gastric tissue of morbidly obese patients. Int J Obes (Lond) 36: 1353-9 [PMID:22083550]

136. Ximenes HM, Hirata AE, Rocha MS, Curi R and Carpinelli AR. (2007) Propionate inhibits glucose-induced insulin secretion in isolated rat pancreatic islets. Cell Biochem. Funct. 25: 173-8 [PMID:16444779]

137. Xiong Y, Miyamoto N, Shibata K, Valasek MA, Motoike T, Kedzierski RM and Yanagisawa M. (2004) Short-chain fatty acids stimulate leptin production in adipocytes through the $G$ protein-coupled receptor GPR41. Proc. Natl. Acad. Sci. U.S.A. 101: 1045-50 [PMID:14722361]

138. Xiong Y, Swaminath G, Cao Q, Yang L, Guo Q, Salomonis H, Lu J, Houze JB, Dransfield PJ and Wang Y et al.. (2013) Activation of FFA1 mediates GLP-1 secretion in mice. Evidence for allosterism at FFA1Mol. Cell. Endocrinol. 369: 119-29 [PMID:23403053]

139. Yonezawa T, Kobayashi $Y$ and Obara Y. (2007) Short-chain fatty acids induce acute phosphorylation of the p38 mitogen-activated protein kinase/heat shock protein 27 pathway via GPR43 in the MCF-7 human breast cancer cell line. Cell. Signal. 19: 185-93 [PMID:16887331]

140. Zaibi MS, Stocker CJ, O'Dowd J, Davies A, Bellahcene M, Cawthorne MA, Brown AJ, Smith DM and Arch JR. (2010) Roles of GPR41 and GPR43 in leptin secretory responses of murine adipocytes to short chain fatty acids. FEBS Lett. 584: 2381-6 [PMID:20399779]

141. Zhang Y, Xu M, Zhang S, Yan L, Yang C, Lu W, Li Y and Cheng H. (2007) The role of G protein-coupled receptor 40 in lipoapoptosis in mouse beta-cell line NIT-1. J. Mol. Endocrinol. 38: 651-61 [PMID:17556534] 